The Israeli Journal of Aquaculture - Bamidgeh, IJA_69.2017.1425, 7 pages

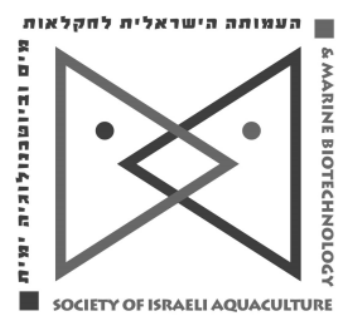

The IJA appears exclusively as a peer-reviewed on-line open-access journal at http://www.siamb.org.il. To read papers free of charge, please register online at registration form.

Sale of $I J A$ papers is strictly forbidden.

\title{
Shewanella putrefaciens: an emerging pathogen for farmed yellow catfish Pelteobagrus fulvidraco
}
Yibin Yang ${ }^{1,2}$, Cheng Guo ${ }^{2,3,4}$, Haipeng $\mathrm{CaO}^{2,3,4 *}$, Liqun $\mathrm{Lu}^{2,3,4}$, Xianle Yang $^{2}$

\author{
${ }^{1}$ Yangtze River Fisheries Research Institute, Chinese Academy of Fishery Sciences, \\ Wuhan Hubei 430223, P.R. China. \\ ${ }^{2}$ National Pathogen Collection Center for Aquatic Animals, Shanghai Ocean University, \\ Shanghai 201306, P.R. China. \\ ${ }^{3}$ Shanghai Collaborative Innovation for Aquatic Animal Genetics and Breeding, Shanghai \\ Ocean University, Shanghai 201306, P.R. China. \\ ${ }^{4}$ Shanghai Engineering Research Center of Aquaculture, Shanghai Ocean University, \\ Shanghai 201306, P.R. China.
}

Keywords: Shewanella putrefaciens; Pelteobagrus fulvidraco; pathogen; antibiotic susceptibility.

\begin{abstract}
Bacteriosis has caused significant economic losses in farmed yellow catfish Pelteobagrus fulvidraco. Information is limited on Shewanella putrefaciens as a pathogen for yellow catfish. In this study, a virulent strain, temporarily named Y2, was isolated from diseased yellow catfish, identified phenotypically and molecularly as $S$. putrefaciens. A phylogenetic tree was constructed to examine isolate $\mathrm{Y} 2$ and compare it to other known isolates. In addition, isolate Y2 is apparently susceptible to aminoglycosides and tetracycline drugs for veterinary use in aquaculture as revealed when screened against a range of common antibiotics. To the best of our knowledge, this is the first report of $S$. putrefaciens as an emerging pathogen for cultured yellow catfish.
\end{abstract}

Corresponding author. Tel: +862781780223; Fax: +862781780223; *

email:yang19890923@yeah.ner; hpcao@shou.edu.cn.

The first two authors contributed equally to this work. 


\section{Introduction}

Yellow catfish Pelteobagrus fulvidraco is an important economic freshwater fish species widely cultivated in China, Japan, Korea, and Southeast Asian countries (Li, 2000). In China, the yellow catfish industry has grown rapidly and is highly profitable (Yang et al., 2009). Production increased to over 355,000 tons in 2015 (Ministry of Agriculture of China, 2016). When cultured intensively however, this industry has been seriously affected by bacterial diseases (Ye, 2009). Bacteriosis should be given more attention to enable further sustainable development of this industry. Studies have shown that several bacterial pathogens such as Aeromonas hydrophila (Liu et al., 2015), Edwardsiella tarda (Deng et al., 2008), Edwardsiella ictaluri (Ye, 2009) and Vibrio mimicus (Zhang et al., 2014) can cause infections in yellow catfish. However, there are few reports on Shewanella putrefaciens infection in farmed yellow catfish.

In June 2017, a severe disease characterized by hemorrhagic skin spots appeared in yellow catfish in major culture regions of Zhejiang and Fujian provinces, China. The disease is highly infectious and lethal, causing over $80 \%$ mortality. In the present study, we isolated and identified a $S$. putrefaciens pathogen as a causative agent for this disease, and determined its taxonomy and antibiotic susceptibility. As far as we know, this is the first report of $S$. putrefaciens as a pathogen for yellow catfish.

\section{Materials and methods}

Fish samples. Twenty diseased yellow catfish averaging $43.1 \pm 2.8 \mathrm{~g}$ were sampled from infected ponds of a fish farm in Huzhou, Zhejiang China in June 2017. The farm had forty acres of ponds with yellow catfish stocked at an initial rearing density of 5,000 juveniles per acre. Water quality during the disease outbreak was $\mathrm{pH} 8.51,0.30 \mathrm{mg} / \mathrm{L}$ total ammonia, $0.04 \mathrm{mg} / \mathrm{L}$ nitrite, and $5.56 \mathrm{mg} / \mathrm{L}$ dissolved oxygen. Diseased samples were placed in sterile bags, kept in ice, and transported to the laboratory.

Bacterial isolation. Each sampled diseased yellow catfish was externally disinfected with $75 \%$ alcohol, and dissected. Samples from livers, kidneys, and spleens, of diseased yellow catfish were streaked onto nutrient brain heart infusion agar (BHIA) plates (Sinopharm Chemical Reagent Co., Ltd.) before conducting careful detection of parasites and viruses using traditional methods as described by Huang et al. (2010) and Ma et al. (2015). After incubation for $24 \mathrm{~h}$ at $28^{\circ} \mathrm{C}$, the dominant uniform isolates were purified by streaking and re-streaking onto BHIA plates. Pure isolates of the predominant uniform colonies were stored at $-80^{\circ} \mathrm{C}$ supplemented with $15 \%$ glycerol. A representative of the dominant isolates, temporarily named $\mathrm{Y} 2$, was characterized further in the present study.

Bacterial identification: Molecular identification. The extraction of genomic DNA from isolate Y2, as well as PCR amplification and sequencing of its 16S rRNA gene were performed as described by Qin et al. (2012). The near complete 16S rRNA gene sequence was assembled using Editseq and Seqman in DNAstar software. A search was performed in the National Centre for Biotechnology Information (NCBI) database for sequence homology using the Basic Local Alignment Search Tool (BLAST) program. A phylogenetic tree from the near complete 16S rRNA gene sequence of the isolate and its homologous sequences was constructed using the neighbour-joining method.

Phenotypic identification. Isolate Y2 was identified phenotypically using API 32E test strips as recommended by Cheng et al. (2013). The test strip was incubated at $37^{\circ} \mathrm{C}$ and observed after $24 \mathrm{~h}$ against the API identification index. The type strain ATCC BAA-1097 of $S$. putrefaciens was used as the control.

Virulence assay. Bacterial virulence was examined by experimentally infecting healthy cultured yellow catfish. One hundred and fifty healthy fish averaging $100 \pm 10 \mathrm{~g}$ were obtained from Baishazhou fishery Co., Ltd. in Wuhan, China. Their health status was evaluated according to the guidelines recommended by Zheng et al. (2012). The experimental fish were acclimated in ten replicate aquaria (each stocked with fifteen fish) supplied with $50 \mathrm{~L}$ of aerated filtered farming water at $25^{\circ} \mathrm{C}$ for 14 days. Prior to the bacterial virulence assay isolate $\mathrm{Y} 2$ was inoculated onto NA plate, incubated at $28^{\circ} \mathrm{C}$ for $24 \mathrm{~h}$, and washed with normal saline into a sterile tube. Cell density was determined by counting colony forming units after a ten-fold serial dilution in sterile distilled water. Two 
replicates of fifteen healthy fish were innoculated by intraperitoneal injection with $0.2 \mathrm{~mL}$ of isolate $\mathrm{Y} 2$ at cell densities of $4.0 \times 10^{4} \mathrm{CFU} / \mathrm{mL}$ to $4.0 \times 10^{7} \mathrm{CFU} / \mathrm{mL}$. Another two replicates of fifteen healthy fish exposed to the same experimental conditions and injected intraperitoneally with $0.2 \mathrm{~mL}$ of normal saline served as the control. Experimental fish were kept at $25^{\circ} \mathrm{C}$ and observed daily for seven days without feeding and water change. Any dead fish were immediately removed and sampled to confirm if mortality was caused specifically by the inoculated isolate. The mean lethal dose $\left(L_{50}\right)$ value is calculated according to the Graphical Probit Method as recommended by Ogbuagu \& Iwuchukwu (2014).

Antibiotic sensitivity assay. The antibiotic sensitivity of isolate Y2 was assayed on NA plates using the Kirby-Bauer disk diffusion method as described by Joseph et al. (2011). Thirteen antibiotic discs were acquired from Hangzhou Tianhe Microorganism Reagent Co., Ltd. The inhibition zones were measured after a $24 \mathrm{~h}$ incubation period at $28^{\circ} \mathrm{C}$. The antibiotic susceptibility was determined according to the manufacturer's guidelines.

\section{Results}

Bacterial identification. A dominant isolate $\mathrm{Y} 2$ was isolated from the diseased yellow catfish and identified by molecular and phenotypic methods as $S$. putrefaciens. Its near complete 16S rRNA gene sequence (1400 nucleotides) was submitted to GenBank database with the accession no. MF401513. A similarity of $99 \%$ was observed in the $16 \mathrm{~S}$ rRNA gene sequence between the $Y 2$ isolate and other $S$. putrefaciens isolates from the GenBank database. The phylogenetic tree confirms that the isolate $Y 2$ is identified with $S$. putrefaciens strain (Figure 1).

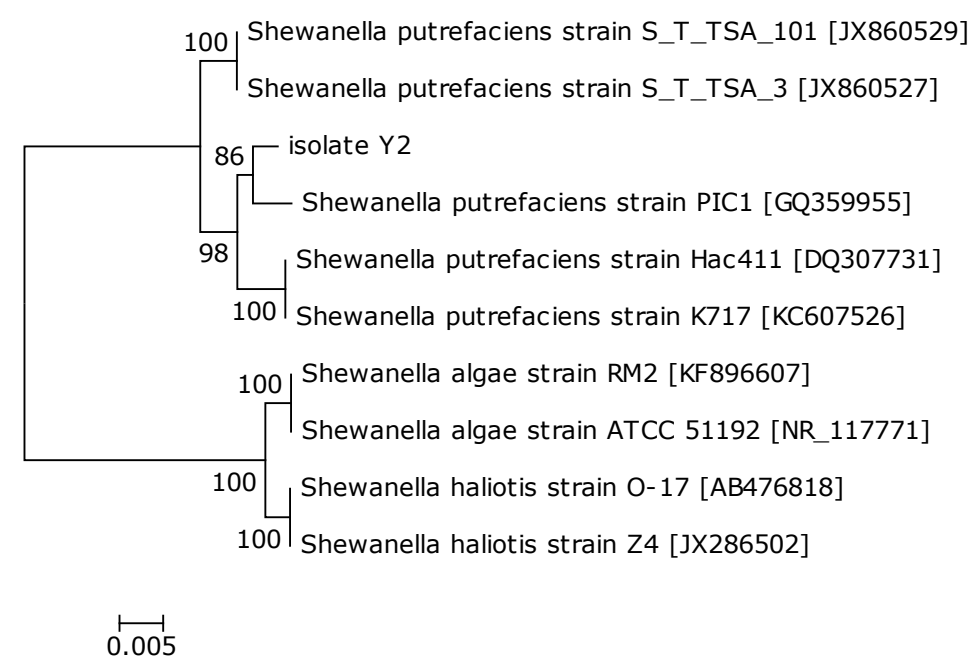

Figure 1. A $16 \mathrm{~S}$ rRNA gene tree of 9 known bacteria and the $\mathrm{Y} 2$ isolate constructed using the neighbour-joining method. The bootstrap values (\%) are shown besides the clades; accession numbers are indicated beside the names of strains, and scale bars represent distance values.

This was confirmed by the phenotypic features as S. putrefaciens (Table 1 ) with $96.88 \%$ identity compared to the reference strain. No parasites and viruses were detected in the diseased yellow catfish from which the isolate Y2 was obtained. 
Table 1. Phenotypic characteristics of isolate $Y 2$.

\begin{tabular}{|c|c|c|}
\hline \multirow[b]{2}{*}{ Tests } & \multicolumn{2}{|c|}{ Reaction } \\
\hline & Y2 & $\begin{array}{l}A T C C \\
B A A-1097\end{array}$ \\
\hline Arginine dihydrolase & $\mathrm{R}^{-}$ & $\mathrm{R}^{-}$ \\
\hline Lysine decarboxylase & $\mathrm{R}^{-}$ & $\mathrm{R}^{-}$ \\
\hline Lipase & $\mathrm{R}^{-}$ & $\mathrm{R}^{-}$ \\
\hline L-aspartate aminase & $\mathrm{R}^{+}$ & $\mathrm{R}^{+}$ \\
\hline$N$-acetyl- $\beta$-glucosaminidase & $\mathrm{R}^{+}$ & $\mathrm{R}^{+}$ \\
\hline$\alpha$-galactosidase & $\mathrm{R}^{-}$ & $\mathrm{R}^{-}$ \\
\hline a-glucosaccharase & $\mathrm{R}^{-}$ & $\mathrm{R}^{-}$ \\
\hline a-maltosidase & $\mathrm{R}^{-}$ & $\mathrm{R}^{-}$ \\
\hline$\beta$-galactosidase & $\mathrm{R}^{-}$ & $\mathrm{R}^{-}$ \\
\hline$\beta$-glucosaccharase & $\mathrm{R}^{-}$ & $\mathrm{R}^{-}$ \\
\hline$\beta$-glucuronidase & $\mathrm{R}^{-}$ & $\mathrm{R}^{-}$ \\
\hline Urease & $\mathrm{R}^{-}$ & $\mathrm{R}^{-}$ \\
\hline Orinithine decarboxylase & $\mathrm{R}^{+}$ & $\mathrm{R}^{-}$ \\
\hline Indole production & $\mathrm{R}^{-}$ & $\mathrm{R}^{-}$ \\
\hline $\begin{array}{l}\text { Malonate utilization } \\
\text { Acid production from }\end{array}$ & $\mathrm{R}^{+}$ & $\mathrm{R}^{+}$ \\
\hline Adonitol & $\mathrm{R}^{-}$ & $\mathrm{R}^{-}$ \\
\hline Galacturonic acid & $\mathrm{R}^{-}$ & $\mathrm{R}^{-}$ \\
\hline Inositol & $\mathrm{R}^{-}$ & $\mathrm{R}^{-}$ \\
\hline L-arabinose & $\mathrm{R}^{-}$ & $\mathrm{R}^{-}$ \\
\hline L-arabitol & $\mathrm{R}^{-}$ & $\mathrm{R}^{-}$ \\
\hline L-rhamnose & $\mathrm{R}^{-}$ & $\mathrm{R}^{-}$ \\
\hline D-arabitol & $\mathrm{R}^{-}$ & $\mathrm{R}^{-}$ \\
\hline D-cellobiose & $\mathrm{R}^{-}$ & $\mathrm{R}^{-}$ \\
\hline D-glucose & $\mathrm{R}^{-}$ & $\mathrm{R}^{-}$ \\
\hline D-maltose & $\mathrm{R}^{-}$ & $\mathrm{R}^{-}$ \\
\hline D-mannitol & $\mathrm{R}^{-}$ & $\mathrm{R}^{-}$ \\
\hline D-sorbitol & $\mathrm{R}^{-}$ & $\mathrm{R}^{-}$ \\
\hline D-sucrose & $\mathrm{R}^{-}$ & $\mathrm{R}^{-}$ \\
\hline D-trehalose & $\mathrm{R}^{-}$ & $\mathrm{R}^{-}$ \\
\hline 5-ketone-potassium gluconate & $\mathrm{R}^{-}$ & $\mathrm{R}^{-}$ \\
\hline Palatinose & $\mathrm{R}^{-}$ & $\mathrm{R}^{-}$ \\
\hline Sodium pyruvate & $\mathrm{R}^{-}$ & $\mathrm{R}^{-}$ \\
\hline
\end{tabular}

$\mathrm{R}^{+}$: positive reaction; $\mathrm{R}^{-}$: negative reaction.

Isolate Y2 was virulent to yellow catfish with a $\mathrm{LD}_{50}$ value of $7.56 \times 10^{5} \mathrm{CFU} / \mathrm{L}$ (Table 2 ). The infected fish exhibited the similar clinical symptom to that seen in the originally diseased fish (Figure 2). When fish were challenged with a concentration of $4.0 \times 10^{7}$ $\mathrm{CFU} / \mathrm{mL}$, acute mortality was observed. Also isolate $\mathrm{Y} 2$ could be re-isolated from experimentally dead fish. No clinical signs or mortality were noted in the control fish.

Table 2. Cumulative mortality of experimental yellow catfish infected by the isolate Y2.

\begin{tabular}{|c|c|c|c|c|c|c|c|c|c|c|c|}
\hline \multirow{2}{*}{ Group } & \multirow{2}{*}{$\begin{array}{l}\text { Concentration } \\
(\mathrm{CFU} / \mathrm{mL})\end{array}$} & \multirow{2}{*}{$\begin{array}{l}\text { Fish } \\
\text { no. }\end{array}$} & \multicolumn{7}{|c|}{$\begin{array}{l}\text { Dead fish no. on day } \\
\text { after challenge }\end{array}$} & \multirow{2}{*}{$\begin{array}{l}\text { Average } \\
\text { cumulative } \\
\text { mortality } \\
(\%)\end{array}$} & \multirow{2}{*}{$\begin{array}{l}L D_{50} \\
\text { value } \\
\text { (CFU/mL) }\end{array}$} \\
\hline & & & 1 & 2 & 3 & 4 & 5 & 6 & 7 & & \\
\hline \multirow{2}{*}{ Control } & \multirow{2}{*}{0} & 15 & 0 & 0 & 0 & 0 & 0 & 0 & 0 & \multirow{2}{*}{0} & \multirow{9}{*}{$7.56 \times 10^{5}$} \\
\hline & & 15 & 0 & 0 & 0 & 0 & 0 & 0 & 0 & & \\
\hline \multirow{2}{*}{ Treatment 1} & $4.0 \times 10^{4}$ & 15 & 0 & 1 & 1 & 1 & 0 & 0 & 0 & \multirow{2}{*}{20} & \\
\hline & & 15 & 0 & 0 & 1 & 1 & 1 & 0 & 0 & & \\
\hline Treatment 2 & $4.0 \times 10^{5}$ & $\begin{array}{l}15 \\
15\end{array}$ & $\begin{array}{l}0 \\
1\end{array}$ & $\begin{array}{l}2 \\
1\end{array}$ & $\begin{array}{l}1 \\
2\end{array}$ & $\begin{array}{l}1 \\
0\end{array}$ & $\begin{array}{l}1 \\
2\end{array}$ & $\begin{array}{l}1 \\
0\end{array}$ & $\begin{array}{l}0 \\
0\end{array}$ & 40 & \\
\hline \multirow{2}{*}{ Treatment 3} & $4.0 \times 10^{6}$ & 15 & 3 & 4 & 2 & 1 & 1 & 0 & 0 & \multirow{2}{*}{70} & \\
\hline & $4.0 \times 10$ & 15 & 2 & 3 & 2 & 1 & 1 & 1 & 0 & & \\
\hline \multirow[t]{2}{*}{ Treatment 4} & $4.0 \times 10^{7}$ & 15 & 4 & 7 & 2 & 2 & 0 & 0 & 0 & \multirow{2}{*}{100} & \\
\hline & & & 5 & 8 & 1 & 1 & 0 & 0 & 0 & & \\
\hline
\end{tabular}




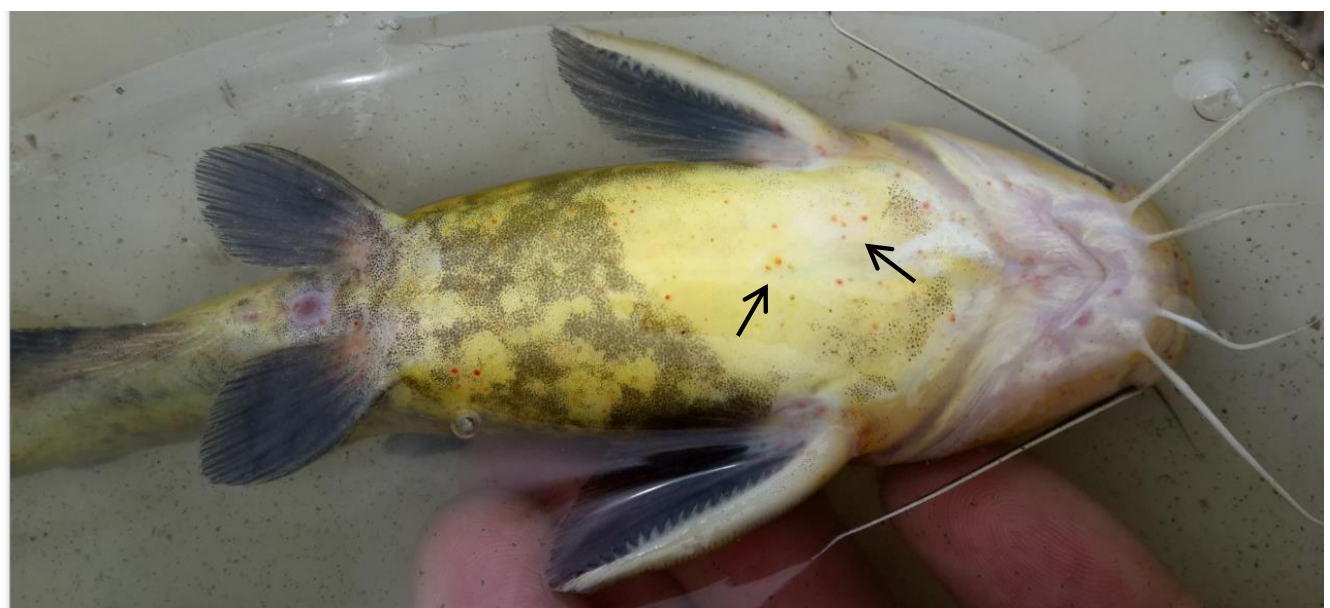

Fig. 2. Pathological symptoms of diseased yellow catfish: arrows show hemorrhagic spots on skin. Antibiotic susceptibility. The antibiotic sensitivity of isolate $\mathrm{Y} 2$ is shown in Table 3. The data indicate that isolate $\mathrm{Y} 2$ is sensitive to amikacin, cefradine, cefotaxime, doxycycline, furazolidone, gentamycin, neomycin, tobramycin, intermediately sensitive to florfenicol, and resistant to the penicillins, sulfonamides antibiotics. This suggests that isolate Y2 has not developed resistance to aminoglycosides and tetracycline antimicrobials.

Table 3. Susceptibility of isolate $Y 2$ to antibiotics.

\begin{tabular}{lll}
\hline Antibiotics & $\begin{array}{l}\text { Content } \\
(\mu \mathrm{g} / \text { disc })\end{array}$ & $\begin{array}{l}\text { Inhibition zone diameter } \\
(\mathrm{mm})\end{array}$ \\
\hline Amikacin & 30 & $24.83 \pm 0.63^{\mathrm{S}}$ \\
Amoxicillin & 20 & $0 \pm 0^{\mathrm{R}}$ \\
Cefradine & 30 & $27.13 \pm 0.19^{\mathrm{S}}$ \\
Cefotaxime $^{*}$ & 30 & $34.60 \pm 0.41^{\mathrm{S}}$ \\
Doxycycline $^{*}$ & 30 & $23.95 \pm 0.23^{\mathrm{S}}$ \\
Florfenicol $^{*}$ & 75 & $15.60 \pm 0.22^{\mathrm{I}}$ \\
Furazolidone $_{\text {Gentamycin }}$ & 300 & $22.85 \pm 0.19^{\mathrm{S}}$ \\
Neomycin $^{*}$ & 10 & $16.07 \pm 0.14^{\mathrm{S}}$ \\
Oxacillin $_{\text {Penicillin }}$ & 30 & $27.71 \pm 0.47^{\mathrm{S}}$ \\
Sulfamethoxazole $^{*}$ & 1 & $0 \pm 0^{\mathrm{R}}$ \\
Tobramycin $^{\mathrm{R}}$ & $10 \mathrm{IU}$ & $9.27 \pm 0.11^{\mathrm{R}}$ \\
\hline
\end{tabular}

Data are presented as the mean \pm standard deviation; SSensitive; Intermediately sensitive; ${ }^{R}$ Resistant.*Antibiotics for aquaculture use.

\section{Discussion}

S. putrefaciens as a pathogen in aquaculture has been documented as causing mortality in Carassius auratus gibelio (Altun et al., 2013; Qin et al., 2012), Babylonia arelolata (Li et al., 2013), Oreochromis niloticus (El-Barbary, 2017), Anguilla anguilla L. (Esteve et al., 2017), Cyprinus carpio L. and Oncorhynchus mykiss (Kozińska \& Pekala, 2004; Pekala et al., 2015). However, there is limited information on S. putrefaciens as a causal agent for cultured yellow catfish. In this study, we characterized the phenotype, taxonomic position, and antibiotic susceptibility of S. putrefaciens Y2. To our knowledge, this is the first report of a $S$. putrefaciens pathogen as a causative agent for farmed yellow catfish.

Various factors are involved in the pathogenesis of fish shewanellosis, including $\beta$ hemolysin production that is closely related to the pathogenicity in S. putrefaciens (ElBarbary, 2017) and external stressors that result in reduced immunity in fish (Kozińska \& Pekala, 2004). Diseases caused by S. putrefaciens are usually associated with these factors. In the present study, the $Y 2$ isolate of $S$. putrefaciens attained an $L D_{50}$ mortality in healthy yellow catfish when challenged with a concentration of $7.56 \times 10^{5} \mathrm{CFU} / \mathrm{mL}$. This 
further demonstrates the potential threat of $Y 2$ to yellow catfish farming. Apart from the virulence of the $\mathrm{Y} 2$ isolate, there might be other secondary factors that induce shewanellosis in yellow catfish, such as high density stocking (Qin et al., 2012) and hypoxic conditions (Esteve et al., 2017); these should also be raised as concerns.

Intensive fish farming has resulted in the massive use of antimicrobials for treatment of fish bacteriosis (Hu et al., 2015). In our study, the Y2 isolate showed resistance to sulfamethoxazole. The same susceptibility has also been observed in S. putrefaciens isolated from Carassius auratus gibelio (Qin et al., 2012), Cyprinus carpio L. and Oncorhynchus mykiss (Kozińska \& Pekala, 2004). The Y2 isolate exhibited sensitivity to doxycycline and neomycin used in the fish farming regions, suggesting that the outbreak of this disease may not have resulted from abuse of these antibiotics.

In conclusion, the present study for the first time reports a S. putrefaciens isolate as a causal agent for cultured yellow catfish. The pathogenicity of the $Y 2$ isolate supports this infection as an emerging threat in yellow catfish farming.

\section{Acknowledgments}

This work has been financially supported by Fishery Sci-Tech Innovation \& Popularization Project of Jiangsu Province (No. Y2017-6), Earmarked Fund for China Modern Shrimp Industry Technology Research (No. nycytx-46), Minhang District Industry-University-Research Institute Program, Shanghai (No. 2016MH252) and Special Fund for Agro-scientific Research in the Public Interest (No. 201503108-CC-1, 201203085).

\section{References}

Altun S., Buyukekiz A. G., Duman M., Ozyigit M. O., Karatas S., Turgay E., 2013. First isolation of Shewanella putrefaciens from gold fish (Carrasius auratus auratus). Isr. J. Aquacult.-Bamidgeh, IJA 66.2014.956.

Cheng P., Zhang F., Li S., Guan X., Yang Z., 2013. Isolation, identification and drug sensitive test on pathogens of skin ulcer from European bream. Aquaculture, 34(10):1-4.

Deng X., Luo W., Tan S., Qiu S., Chen K., 2008. Isolation and identification of bacteriosis pathogen-Edwardsiella tarda from yellow catfish (Pelteobagrus fulvidraco) with red head disease. Oceanologia et Limnologia Sinica, 39(5): 511-516.

EI-Barbary M.I., 2017. First recording of Shewanella putrefaciens in cultured Oreochromis niloticus and its identification by 16S rRNA in Egypt. Egyptian J Aquat Res., 43(1): 101-107.

Esteve C., Merchán R., Alcaide E., 2017. An outbreak of Shewanella putrefaciens group in wild eels Anguilla anguilla L. favoured by hypoxic aquatic environments. J Fish Dis., 40: 929-939.

Hu L., Zhu S., Peng L., Xu F., Zhou Z., Cai Y., 2015. The harm and problem analysis of drug abuse in aquaculture. Chinese J Fish., 28(2): 47-54.

Huang Y., Li X., Wu X., Pang Y., Huang G., Wei X., Tong G., 2010. Detection and diagnosis procedure for fish parasitic diseases. Fisheries Science \& Technology Information, 37(2):83-85.

Joseph N.M., Sistla S., Dutta T.K., Badhe A.S., Rasitha D., Parija S.C., 2011. Reliability of Kirby-Bauer disk diffusion method for detecting meropenem resistance among non-fermenting gram-negative bacilli. Indian J Pathol Microbiol., 54(3): 556-560.

Kozińska A., Pekala A., 2004. First isolation of Shewanella putrefaciens from freshwater fish-a potential new pathogen of the fish. Bull European Assoc Fish Pathol., 24:199-203.

Li M., 2000. Artificial farming feasibility and practical technology of yellow catfish Pelteobagrus fulvidraco. Feed Res., 11: 40-41.

Li S., Qiu D., Zhang J., Yang S., Jia C., Qiu M., 2013. Study on microflora of pathogenic and conditional pathogenic bacteria in Babylonia areolate attacked by shellflesh separating disease and proboscis edema-disease. Advances in Marine Science, 31(2): 266-272. 
Liu J., Long Y., Huang J., Liang J., Hu D., Long S., Niu Z., Peng Y., Zhi Q., 2015. Isolation, identification and virulence genes detection of bacterial pathogen from Pelteobagrus fulvidraco Richardson with fulminant epidemic. Freshwater Fisheries, 45(2): 56-61.

Ma J., Jiang N., Liu W., Zhou Y., Wen H., Zeng L., 2015. Preliminary observation of a viral agent by electron microscopy associated with an epizootic mortality in farmed tilapia. Freshwater Fisheries, 45(6):94-96.

Ministry of Agriculture of China, 2016. China Fishery Statistical Yearbook. Beijing: China Agriculture Press, $31 \mathrm{pp}$.

Ogbuagu D.H., Iwuchukwu E.I., 2014. Evaluation of the toxicity of three hair shampoos on the catfish (Clarias gariepinus) fingerlings. Applied Ecol Environ Sci., 2(3): 86-89.

Pekala A., Kozinska A., Pazdzior E., Glowacka H., 2015. Phenotypical and genotypical characterization of Shewanella putrefaciens strains isolated from diseased freshwater fish. J Fish Diseases, 38: 283-293.

Qin L., Zhang X., Bi K., 2012. A new pathogen of gibel carp Carassius auratus gibelioShewanella putrefaciens. Acta Microbiologica Sinica, 52(5): 558-565.

Yang R., Xie C., Fan Q., Gao C., Fang L., 2009. Histological and ultrastructural studies of the stomach and intestine in larvae of yellow catfish Pelteobagrus fulvidraco. Acta Hydrobiologica Sinica, 33(6):1068-1077.

Ye S., Li H., Qian G., Li Z., 2009. First case of Edwardsiella ictaluri infection in China farmed yellow catfish Pelteobagrus fulvidraco. Aquaculture, 292: 6-10.

Zhang X., Li Y., Mo Z., Luo X., Sun H., Liu P., Li A., Zhou S., Dan X., 2014. Outbreak of a novel disease associated with Vibrio mimicus infection in fresh water cultured yellow catfish, Pelteobagrus fulvidraco. Aquaculture, 432: 119-124.

Zheng W., Cao H., Yang X., 2012. Grass carp (Ctenopharyngodon idellus) infected with multiple strains of Aeromonas hydrophila. African J Microbiol Res., 6(21):4512-4520. 